\title{
Formas Variantes do Jmperativo de Segunda Pessoa nos Séculos XJX e XX: a expressão do social ${ }^{1}$
}

\begin{abstract}
Variants Imperative Forms of SeCond Person in Centuries XIX and XX: SOCIAL EXPRESSION
\end{abstract}

Márcia Cristina de Brito Rumeu*

Resumo: Neste trabalho, buscam-se rastros da realidade sincrônica do português brasileiro em relação à expressão gramatical variável do imperativo de $2^{a}$ pessoa do singular ((“fala você") versus ("Agora seja tu o laso de união..." ${ }^{2}$ (1919)). Com base na análise de missivas pessoais oitocentistas e novecentistas, redigidas por brasileiros cultos e integrantes de uma mesma família brasileira (a família Pedreira Ferraz-Magalhães) cujos perfis sociolinguísticos foram identificados (CONDE SILVESTRE, 2007; ROMAINE, 2010; HERNÀNDEX-CAMPOY; CONDE SILVESTRE, 2014), reflete-se sobre

\footnotetext{
* Doutora em Língua Portuguesa pela Faculdade de Letras da UFRJ (2008). Professora Doutora Adjunto IV - Universidade Federal de Minas Gerais (UFMG). Contato: marciarumeu@uol.com.br.
}

${ }^{1}$ Este trabalho está vinculado ao Projeto Para uma Sociolinguística Histórica do Português Brasileiro: Variação Sincrônica e Mudança Diacrônica. Participou desta Pesquisa Juliana Sander Diniz, Bolsista de Iniciação Científica - FAPEMIG (Fundação de Amparo à Pesquisa do Estado de Minas Gerais, FALE/UFMG) .

${ }^{2} \mathrm{O}$ dado em questão pertence ao conjunto de missivas da família Pedreira FerrazMagalhães. "[...] Meu consolo é resar por ella, e chorar. Espero que me escrevas contando tudo que lhe diz respeito, pôde fazer os Votos. Que doença foi? Já te imaginarás todo meu soffrimento! Agora seja tu o laso de união entre todos, porem com prudencia, sobretudo com ás Dorothéas". (Carta redigida por uma mulher (MRPCAM), com 41 anos, ao irmão (JPCAM), com 38 anos. Montevidéu, 11.09.1919). 
a representatividade das categorias sociais gênero e faixa etária para a investigação acerca da expressão variável do imperativo de $2^{\text {a }}$ pessoa. Na perspectiva de uma análise metodologicamente orientada pela sociolinguística quantitativa de base laboviana (LABOV, 1994, 2001), confirma-se a hipótese de que o imperativo abrasileirado, nos termos de Scherre (2007), tende a se firmar no português brasileiro, visto que os jovens pareceram encaminhar-se na direção histórica da mudança em progresso.

Palavras-chave: Imperativo gramatical. Alternância tu/você. Variação linguística.

Abstract: In this text, looking to trace the synchronic reality of Brazilian Portuguese on the variable imperative grammatical expression of the second person singular (“fala você") vs. ("Agora seja tu o laso de união...",1919)). Based on the analysis of $19^{\text {th }}$ and $20^{\text {th }}$ century personal letters, written by educated Brazilians, members of a same Brazilian family (the Pedreira Ferraz-Magalhaes family), whose sociolinguistic profiles have beenidentified (CONDE SILVESTRE, 2007; ROMAINE, 2010; HERNÀNDEX-CAMPOY; CONDE SILVESTRE, 2014), the results expound the representativeness of Gender and Age group as significant social categories for research on the variable imperative grammatical expression of the second person singular. Following the orientation of Labov's methodological quantitative sociolinguistic analysis (LABOV, 1994,2001), is confirmed the hypothesis that the abrasileirado imperative, in terms of Scherre (2007), tends become established in Brazilian Portuguese as young people seemed be heading in the historic direction of change in progress.

Keywords: Imperative grammatical. Tu/você variation. Linguistic variation.

\section{Considerações Iniciais}

As formas tu e você se revezam, com distintos níveis de produtividade, na referência ao sujeito de segunda pessoa do singular (doravante $2 \mathrm{P}$ ) tanto no eixo diatópico quanto no eixo sociointeracional, conforme já averiguado em diversificados corpora de língua falada, por pesquisadores voltados para a realidade sincrônica do português brasileiro (doravante PB). À luz de uma 
compilação dos resultados das principais análises acerca da variação $t u / v o c \hat{e}$, Scherre et al. (2015) detectaram a funcionalidade de seis subsistemas tratamentais $^{3}$ no PB atual que, segundo Lopes e Cavalcante (2011, p. 39), podem ser sumarizados em três: (I) o subsistema de você (regiões Centro-Oeste, Sudeste), (II) o subsistema de $t u$ (Nordeste, Norte, Sul) e (III) o subsistema da alternância você/tu (regiões Centro-Oeste, Sudeste, Sul, Nordeste, Norte). Acrescente-se, a essa configuração sincrônica variável de referência à $2 \mathrm{P}$ entre os brasileiros, o fato de as construções imperativas também evidenciarem uma composição estrutural variável, seja com formas de indicativo (fala comigo.), seja com formas de subjuntivo (fale comigo.). Nesse sentido, identificou Scherre (2007) um "corte geográfico" no que se refere à expressão variável do imperativo cuja expressão binária mostra-se desvinculada de um sistema de distribuição complementar entre as formas pronominais tu e você. A prevalência do imperativo com formas de indicativo (deixa/ recebe/abre/dá/diz/vai) se deu nas regiões Sul, Sudeste e Centro-Oeste brasileiras, ao passo que, nas capitais nordestinas Fortaleza, João Pessoa e Salvador, o imperativo com formas de subjuntivo (deixe/receba/abra/dê/ diga/va) assumiu maior produtividade, destoando dos resultados das construções imperativas do recifense que, por sua vez, manteve simetria entre as formas variáveis de constituição do imperativo (deixa vs. deixe, recebe vs. receba, abre vs. abra, dá vs. dế; diz vs. diga, vai vs. vâa. Mais interessante ainda é o fato de que, no município catarinense de Lages, cujos resultados para o imperativo também destoam dos demais trabalhos da região Sul, foi

${ }^{3}$ Os seis subsistemas pronominais a seguir expostos foram discutidos por Scherre et al. (2015), ao descreverem as estratégias pronominais de tratamento da $2^{a}$ pessoa do discurso do PB atual, relacionando-as também ao fenômeno da concordância verbal (Tu e Você em concordância com formas verbais de $2^{a}$ e $3^{a}$ pessoas do discurso): Subsistema I: Predomínio de Vocênas regiões Centro-Oeste, Sudeste, Sul e Nordeste; Subsistema II: Predomínio de Tu com concordância muito baixa nas regiões sul e norte; Subsistema III: Equilíbrio de Tu/Você com concordância muito baixa para o $T u$ na região sul; Subsistema IV: Predomínio de Tu com concordância média nas regiões Sul, Nordeste e Norte; Subsistema V: Uso variável de Você/Tu ou Tu/Você sem concordância nas regiões Sul, Sudeste, Centro-Oeste, Nordeste e Norte; Subsistema VI: Tu/Você ou Você/Tu com concordância médio-baixa nas regiões Sul e Nordeste. 
verificada, por Bonfá, Pinto e Luiz (1997, p. 10-11), a preferência pelo imperativo com formas de indicativo em um contexto de alta frequência de uso do você-sujeito (85\%) (LOREGIAN-PENKAL, 2004, p. 133).

Considerando o fato de Scherre (2007) ter observado que a alternância entre formas de indicativo e de subjuntivo na confecção do imperativo alcança também uma distribuição geográfica, buscam-se, neste estudo, evidências históricas dessa marca diatópica na produção escrita de cariocas cultos entre a $2^{a}$ metade do século XIX e a $1^{a}$ metade do século XX. Pretende-se, neste artigo, refletir sobre o processo de formação do imperativo abrasileirado (o indicativo verbal associado ao você-suj. de $2 \mathrm{P}$, como na sentença amplamente divulgada no espaço midiático: 'Vem pra Caixa você também'), nos termos de Scherre (2007, p. 210), como um das repercussões da inserção do você no sistema pronominal do PB. O foco desta análise está voltado especificamente para a expressão gramatical variável do imperativo no $\mathrm{PB}$, principalmente em contextos de tu e você como sujeitos de $2 \mathrm{P}$ do discurso, tendo em vista, sobretudo, as influências das categorias sociais gênero e faixa etária dos cariocas cultos inseridos no contexto sócio-histórico oitocentista e novecentista do PB. A realidade sincrônica do $\mathrm{PB}$ em relação ao imperativo de $2 \mathrm{P}$ é adotada como ponto de partida para a reconstrução do gradualismo do processo de inserção do você no quadro pronominal e seus impactos nas construções imperativas de 2P. Nesta análise, acolhem-se especificamente as estruturas imperativas variáveis que, alicerçadas com formas de indicativo (imperativo verdadeiro) ou com formas de subjuntivo (imperativo supletivo), podem estar correlacionadas, já em sincronias passadas (fins do século XIX e $1^{\text {a }}$ metade do século XX), aos pronomes tu e você (o imperativo abrasileirado), ainda que estudos linguísticos precursores, tais como o de Faraco (1982) e o de Menon (1984) já tenham se voltado para o imperativo em cuidadosas análises.

As questões condutoras desta reflexão são as seguintes: (i) o você-sujeito seria mais produtivo em que tipo de construção imperativa de $2 \mathrm{P}$ (com formas de subjuntivo ou com formas de indicativo) nos séculos XIX e XX, já que, segundo Sampaio (2001, p. 61-62), na década de 90 do século XX, os cariocas assumiram o imperativo com formas de indicativo?; (ii) em que nível o imperativo abrasileirado (o imperativo construído com formas de indicativo em contexto de você-sujeito) já estaria evidente, através da análise da produção escrita de brasileiros cultos, em sincronias passadas do PB? Com 
base nessas questões, formulam-se as seguintes hipóteses: (I) conjectura-se que, na escrita culta carioca oitocentista e novecentista, o você se mostrasse bem mais produtivo, sobretudo nas construções de imperativo estruturadas com formas de subjuntivo, ainda que em alternância com as formas de indicativo (imperativo abrasileirado); (II) prevê-se que o gênero e a faixa etária dos missivistas já sugerissem, em algum nível, indícios do avanço do imperativo abrasileirado em fins do século XIX, bem como na $1^{a}$ metade do século $\mathrm{XX}$, tendo em vista o fato de tais categorias sociais terem se mostrado relevantes na análise do a gente, pronome que se gramaticalizou (LOPES, 2003), assim como o você (gente [nome] > a gente [pronome]; mercê [nome] vossa mercê [pronome de tratamento] > você [pronome]).

Este texto estruturalmente está composto por cinco seções. Nas considerações iniciais, situa-se a discussão sobre o imperativo, considerando as questões motivadores, o objetivo principal e as hipóteses que orientaram o tema em análise. Na sequência, esclarecem-se alguns traços morfossintáticos de expressão do imperativo gramatical do PB à luz de Cardoso (2006) e, a seguir, expõem-se os pressupostos teórico-metodológicos e os corpora. Discutem-se, na análise dos dados, os resultados gerais das construções imperativas, atentando especificamente para a influência das categorias sociais gênero e faixa etária em relação à distribuição variável do imperativo verdadeiro e do imperativo supletivo. Sistematizam-se, nas considerações finais, algumas generalizações acerca da produtividade variável das construções imperativas de 2P na escrita culta carioca dos séculos XIX e XX.

\section{$1 \mathrm{O}$ Você nas Construções de Imperativo de 2P: critérios norteadores}

Em língua portuguesa, o modo verbal imperativo é regido por uma força ilocutória (SEARLE, 1969), capaz de imprimir, ao ato verbal, valores de ordem, pedido, sugestão (CUNHA; CINTRA, 1985). Segundo Mateus, Brito e Faria (2003), o modo imperativo é caracterizado pela diretividade do ato ilocutório, imprimindo-lhe a intenção comunicativa motivada por fatores discursivos, pragmáticos e morfossintáticos. Tendo em vista os objetivos deste trabalho, volta-se o foco, nesta seção, para a discussão dos padrões morfológicos e sintáticos que tendem a determinar a força ilocutória imperativa no PB. Acolhe-se como ponto de partida a tradicional concepção 
de imperativo gramatical, trazendo à discussão algumas informações provenientes de cuidadosos estudos linguísticos mais recentes, tais como os de Cardoso (2006) e de Scherre (2007).

À luz da gramática tradicional, o imperativo afirmativo é construído com formas próprias para as segundas pessoas do singular (canta tu) e do plural (cantai vós). As demais pessoas do discurso provêm integralmente do presente do subjuntivo (cantemos nós, cantem vocês). Por outro lado, o imperativo negativo não apresenta formas próprias, sendo totalmente proveniente do presente do subjuntivo (não cantes tu, não cante você, não cantemos nós, não canteis vós, não cantem vocês) (cf. Rocha Lima, 2002, p. 129; Cunha e Cintra, 1985, p. 465). Tal distinção, respaldada pela norma gramatical em relação às formas das segundas pessoas do singular e do plural do presente do indicativo (Faz. a lição agora!/ Faz̧ei a lição agora!) e as formas advindas do presente do subjuntivo (Ame a sua vida/Não engane a si mesmo) são entendidas, respectivamente, como expressões de imperativo verdadeiro e de imperativo surrogate (RIVERO, 1994; RIVERO; TERZI, 1995) ou imperativo supletivo (MATEUS; BRITO; FARIA, 2003).

Na realidade linguística do PB, os estudos de Scherre (2004, 2007) voltam-se para a variação entre as formas imperativas fale agora/fala agora; abre aqui/abra aqui, assumindo também como fomentadoras dessa discussão as sentenças "Vem pra Caixa você também. Vem!”; "Faz um 21"; "Me liga! Ligue para a Net Rio"; "Nayara, pára de conversar com o Rangel que você tá atrapalhando ele", nas quais é possível observar que o "você, apesar de não apresentar traços formais, apresenta os traços semânticos de segunda pessoa", conforme discutido por Lopes e Cavalcante (2011, p. 61). Nesse sentido, entende-se, em diálogo com tais autoras, que não seja possível manter, sobretudo na análise do imperativo de $2 \mathrm{P}$, o discurso de "mistura de formas pronominais" atribuída à convivência entre formas de $2 \mathrm{P}$, vinculadas ao $t u$, e de formas de $3 \mathrm{P}$, vinculadas ao você, visto tratar-se de estratégias idênticas em relação à pessoa semântica (2P), ao evocarem o [-EU] (LOPES; RUMEU, 2007). Acrescente-se ainda o fato de que a coexistência de formas de tu e de você já ter sido comprovadamente observada como eficaz na produção escrita de escreventes cultos brasileiros em fins do século XIX (LOPES, 2005, p. 57-64; RUMEU, 2013).

Cardoso (2006), ao discutir aspectos morfológicos e sintáticos do imperativo gramatical brasileiro, compartilha da compreensão (já amplamente 
divulgada) de que a inserção e a consequente produtividade do pronome você no quadro pronominal do $\mathrm{PB}$ é resultado de um paulatino e gradual processo de gramaticalização (Vossa Mercê $>$ Você) marcado pela referência semântica à $2 \mathrm{P}$ do discurso em concordância formal com estruturas verbais de 3P. Acrescente-se, ainda, a percepção da produtividade do tu como pronome de $2 \mathrm{P}$ do discurso sem concordância, conforme divulgado por Scherre et al. (2015), em relação ao subsistema de $t u$, e também discutido por Lopes e Cavalcante (2011). Assim sendo, neutralizaram-se, nas formas tu canta, você canta, ele/ ela canta, as distinções formais entre formas de $2 \mathrm{P}$ e de $3 \mathrm{P}$ relacionadas aos pronomes de $2 \mathrm{P}$, tu e você. No século $\mathrm{XX}$, passa a predominar o você, que tanto se expressa em construções de imperativo verdadeiro (fala, abre, faz) como em construções imperativas supletivas (fale, $a b r a, f a c ̧ a)$ com idêntico valor de verdade e sem caráter pejorativo (SCHERRE, 2007).

Na discussão acerca dos aspectos sintáticos do $\mathrm{PB}$ relevantes à análise das construções imperativas, Cardoso (2006) se refere à realização nula do sujeito e ao uso da forma verbal subjuntiva na oração independente. Para Cardoso, a ausência de sujeito explícito na oração pode ser entendida como uma estratégia de expressão do imperativo no PB. Em períodos como Faz. a lição de casa em oposição a Você faz a lição de casa, percebe-se nesta sentença uma leitura assertiva, ao passo que, naquela, há uma interpretação imperativa, impondo-se ao sujeito de $2 \mathrm{P}$ (Você) a realização da ação proposta (fazer a lição de casa). Dessa forma, ao contrapor o período Faça a lição de casa ao período Espero que você faça a lição de casa, observam-se, respectivamente, as expressões imperativa e volitiva do enunciador. Na oração independente, o uso da forma verbal subjuntiva também constitui um aspecto sintático, apontado por Cardoso (2006) como assegurador da força ilocutória imperativa. Observa-se, pois, a expressão do objetivo ilocutório imperativo em construções cujos sujeitos gramaticais de $2 \mathrm{P}$ do discurso não foram realizados foneticamente.

Com base na discussão acerca dos aspectos morfológicos e sintáticos do imperativo gramatical que lhe asseguram a força ilocutória imperativa, é possível chegar a duas generalizações relacionados à categoria gramatical do imperativo no PB. São elas: (i) a pronominalização do vossa mercê até originar o você correlacionada à consequente neutralização entre as formas verbais 
imperativas de $2 \mathrm{P}$ e $3 \mathrm{P}$ do discurso ("Vem pra Caixa você também”) parece estar intrinsecamente associada ao uso variável do imperativo gramatical do PB; (II) o emprego de formas verbais indicativa ou subjuntiva aliada à não expressão do sujeito pronominal de $2 \mathrm{P}$ (sujeito nulo de $2 \mathrm{P}$ ), na oração independente, constituem aspectos sintáticos que também se prestam a assegurar ao imperativo gramatical a sua especificidade ilocutória.

Uma vez expostos alguns traços pragmáticos e morfossintáticos do imperativo gramatical do $\mathrm{PB}$, passa-se à fundamentação teórica, sociolinguística histórica, norteadora desta reflexão.

\section{Fundamentação Teórico-Metodológica}

\subsection{Alguns pressupostos da sociolinguistica histórica em análises do português brasileiro}

A função da linguística histórica é detectar as diferenças linguísticas entre o passado e o presente, entendendo os movimentos de variação e mudança como manifestações expressivas da constituição interna das línguas humanas (LABOV, 1994, 2001). Nesse sentido, os trabalhos em sociolinguística histórica podem ser obstaculizados por não ser tão simples inferir quanto o passado foi diferente do presente. Acredita-se que a força propulsora da mudança linguística atuante outrora continua a influenciar a realidade linguística sincrônica (o uniformitarismo da mudança), como reflexo do princípio norteador da mudança nas línguas humanas - The uniformitarian principle, segundo Labov (1994). Nesse sentido, a adoção da realidade linguística presente como ponto de partida para a compreensão histórica do estatuto variável do imperativo do PB concretizou-se através do paradoxo diacrônico (Historical paradox).

No que se refere especificamente à (re)constituição histórica do PB, assume-se, em harmonia com Lucchesi (1998, p. 74), a realidade linguística brasileira "não apenas como heterogênea e variável, mas também como uma realidade plural; mais especificamente, como uma realidade polarizada". Nesse sentido é conduzida a argumentação acerca da heterogeneidade linguística do PB marcada pela polarização de normas expressa através da convivência do português substandard (normas populares) com o português standard (normas cultas). Com base na noção de português standard, justifica-se 
que esta análise linguística embasada na escrita culta cotidiana do PB se fixe no intuito de contribuir para a caracterização da expressão objetiva da norma culta escrita ainda em construção que, de acordo com Pagotto (1999), foi habilmente fixada "à imagem e semelhança" do português europeu (doravante PE) e amparada pela força do discurso científico, no Brasil do século XIX. Assim sendo, justifica-se o trabalho com base em cartas familiares pelo fato de tratar-se de uma produção escrita mais livre da pressão da norma-padrão, tendendo a evidenciar, pois, a norma objetiva (CUNHA, 1985, p. 52) do PB. O recorte temporal é outro aspecto relevante ao estudo em questão, visto que o você, no século XVIII, como visto em Rumeu (2004), ainda se comportava como uma forma pronominal de tratamento, o que permite postular que, em fins do século XIX e no século XX, seja possível entrever evidências da consequente reorganização do sistema pronominal na estruturação formal do imperativo de $2 \mathrm{P}$.

É desafiante o resgate de realidades linguísticas pretéritas à luz de textos escritos remanescentes (CONDE SILVESTRE, 2007; ROMAINE, 2010; HERNÀNDEX-CAMPOY; CONDE SILVESTRE, 2014), impondo ao linguista-pesquisador que redobre a sua atenção em relação ao "problema dos filtros" como uma preocupação pertinente tanto aos estudos de língua escrita quanto aos de língua falada (ROMAINE, 2010). Tendo em vista o desejo de descrever e de analisar realidades linguísticas passadas através de documentos escritos, que, por sua vez, são os únicos representantes de fases linguísticas muito recuadas no tempo, deve-se atentar também ao fato de que traços da língua oral podem se misturar a hábitos de língua escrita (AGUILLAR, 1998). Nesse sentido, é legítimo que o linguista-pesquisador se cerque de critérios em relação à constituição de um conjunto de textos que se aproxime da espontaneidade da fala e que esteja criteriosamente organizado não só em relação à delimitação do seu contexto de produção (homogêneas amostras de epístolas certificadamente produzidas por brasileiros letrados entre fins do século XIX e a $1^{\text {a }}$ metade do século XX), mas também no que se refere à caracterização do perfil social do missivista - origem (nacionalidade e naturalidade), filiação, idade, gênero (sexo), nível de escolaridade, representação social) -, nos moldes de Rumeu (2013), inspirados em Lobo (2001). 
Uma vez expostos alguns dos pressupostos básicos da sociolinguística histórica, passa-se à exposição da metodologia adotada para o trabalho com missivas dos séculos XIX e XX.

\subsection{A metodologia de trabalho com corpora históricos: as missivas e os informantes}

Na perspectiva da sociolinguística variacionista de orientação laboviana, volta-se o foco não só para a configuração interna da língua, como previa Saussure (2008), mas também para a sua configuração social, concebendo-a como um sistema movido por heterogeneidade ordenada cujas manifestações linguísticas variáveis podem ser descritas e analisadas nos seus níveis estrutural e social (WEINREICH; LABOV; HERZOG, 1968). Partindo da realidade linguística atual do $\mathrm{PB}$, no intuito de reconstruir sincronias passadas à luz dos princípios da sociolinguística histórica pensados por Lobo (2001), Conde Silvestre (2007), Romaine (2010) e Hernàndex-Campoy e Conde Silvestre (2014), há que atentar aos possíveis percalços do trabalho com dados linguísticos de sincronias passadas, tais como os já apontados por Labov (1994, p. 11): hipercorreção, mistura dialetal e "erros" do escriba. Nesse sentido, o processo de construção de amostras de língua escrita representativas de realidades linguísticas pretéritas que subsistiram ao tempo requer do linguista-pesquisador o refinamento metodológico adequado às específicas amostras textuais com o intuito não só de reconhecer, mas também de distinguir traços do vernáculo do $\mathrm{PB}$ em relação às especificidades do redator do manuscrito, conforme discutido por Rumeu (2013, p. 111).

As 158 correspondências familiares que subsidiaram esta análise foram mantidas entre os cariocas da família Pedreira Ferraz-Magalhães. Nessas missivas, vem à tona a intimidade de brasileiros letrados (epístolas entre pais e filhos, entre irmãos), em intercâmbios comunicativos de informalidade, caracterizados pela aproximação afetiva entre o remetente e o destinatário. Tendo em vista o caráter pessoal dessas cartas, aspectos rotineiros da vida cotidiana brasileira, de fins do século XIX e alvorecer do século XX (1872 e 1948), permite que se entenda tal amostra como sui generis para o reconhecimento da história da vida privada de uma família brasileira nascida no Rio de Janeiro, que muito viajou da capital carioca para o interior e por outros espaços sociogeográficos dentro e fora do Brasil. 
Com o intuito de construção de uma sociolinguística histórica do português, adotaram-se os seguintes procedimentos metodológicos relacionados a um conjunto de 170 cartas trocadas entre os membros da família carioca Pedreira Ferraz-Magalhães: (I) primou-se pelo levantamento e identificação do perfil social dos missivistas com base no controle do gênero (sexo), da faixa etária, do nível de escolaridade e da função social; (II) cotejaram-se as várias missivas para a devida constatação acerca da versão autógrafa das epístolas familiares, tornando possível a comprovação de que realmente foram escritas e assinadas pelo missivista em questão; (III) optou-se pela confecção de uma conservadora edição das cartas familiares cariocas, o que consiste na reprodução fac-similar e transcrição do manuscrito sem qualquer intervenção do editor em relação à grafia, à pontuação e às demais práticas textuais específicas de fins do século XIX e da $1^{\mathrm{a}}$ metade do século XX. Isso posto, parte-se dos resultados acerca do estatuto variável do imperativo de 2P no PB (SCHERRE, 2007) para o levantamento dos dados, submetidos, por sua vez, às seguintes categorias linguísticas (estruturais) e extra-linguísticas (sociais): (I) as formas imperativas de $2 \mathrm{P}$ vinculadas ao indicativo ou ao subjuntivo aos quais os dados estavam vinculados como evidência da variável dependente; (II) a forma de tratamento específica na função de sujeito de 2P (carta de $t u-s u j$., carta de você/(s)-suj. ${ }^{4}$, carta de $t u$ e você (mista), carta com outra forma nominal de tratamento na referência ao sujeito de 2P do discurso; (III) o tipo de conjugação verbal (1 $1^{\mathrm{a}}, 2^{\mathrm{a}}, 3^{\mathrm{a}}$ conjugações); (IV) o número de sílabas do verbo em sua forma não finita; (V) o paralelismo formal e semântico; (VI) o paralelismo fônico; (VII) a polaridade da estrutura (negativa versus afirmativa); (VIII) o gênero do missivista (masculino ou feminino); (IX) a faixa etária do missivista (jovem, adulto ou idoso). À luz das orientações metodológicas da pesquisa sociolinguística quantitativa de base laboviana (PAIVA; DUARTE, 2004; MOLLICA; BRAGA, 2004; GUY;

${ }^{4}$ Consciente do fato de que a função de sujeito de $2 \mathrm{P}$ somente poderia ser marcada pelo tu ou pelo você, levantaram-se também os dados de imperativo em cartas de vocês-suj. que se expressaram em pouquíssimas cartas de fins do século XIX com o intuito de depreender a expressão do imperativo em missivas que já evidenciassem a expressão da forma gramaticalizada "você", ainda que em sua forma pluralizada ("vocês"). 
ZILLES, 2007), as ocorrências de imperativo de 2P foram quantificadas e submetidas ao pacote de programas Goldvarb, não só para o cálculo das suas frequências de uso, mas também para a depreensão dos seus índices probabilísticos (análise em peso relativo) que, nesta análise, somente serão expostos para a função de sujeito de $2 \mathrm{P}$ (cartas de tu-suj., cartas de você-suj., cartas de $t u / v o c \hat{e}-s u j$.), uma vez que legitima a percepção do contexto do sujeito de $2 \mathrm{P}$ que, no caso do imperativo abrasileirado, é o de você. Acrescente-se a essa justificativa também o fato de este trabalho se dedicar à discussão da influência das categorias sociais gênero e faixa etária para a distribuição variável do imperativo de $2 \mathrm{P}$, seja com formas de indicativo, seja com formas de indicativo nos contextos de tu-suj., você-suj. e de alternância entre as formas $t u / v o c e$ também na função de sujeito de $2 \mathrm{P}$.

Resguardadas as hipóteses específicas à codificação dos dados de imperativo em relação aos grupos de fatores já testados nas análises de Scherre (2004, 2007), passa-se à discussão, inicialmente, dos resultados gerais acerca da alternância entre as formas de indicativo e de subjuntivo na estruturação do imperativo de $2 \mathrm{P}$ e, na sequência, é possível correlacioná-los especificamente aos condicionamentos sociais, tais como o gênero e a faixa etária dos missivistas cariocas.

\section{As Construções de Imperativo de $2^{\mathrm{a}}$ Pessoa nas Cartas Cariocas Oitocentistas e Novecentistas}

\subsection{Distribuição geral das construções imperativas de $2^{a}$ pessoa: a alternância entre 0 imperativo supletivo e o imperativo verdadeiro}

Considerando a expectativa de expressão variável do imperativo de 2P nas cartas dos missivistas cariocas da família Pedreira Ferraz-Magalhães, entre fins do século XIX e $1^{\mathrm{a}}$ metade do século XX, passa-se, com base na análise do Quadro 1, aos resultados percentuais das construções imperativas distribuídas entre as formas de indicativo e as formas de subjuntivo. 
Quadro 1 - O imperativo construído com formas de indicativo e de subjuntivo correlacionado às cartas de tu e você-suj. (mistas), cartas de $t u-s u j$. e cartas de você-suj

\begin{tabular}{|c|c|c|}
\hline \multirow{2}{*}{$\begin{array}{c}\text { SUJEITOS PRONOMINAIS } \\
\text { DE } 2^{\text {a }} \text { PESSOA }\end{array}$} & \multicolumn{2}{|c|}{ IMPERATIVO DE $2^{\mathrm{a}}$ PESSOA } \\
\hline & INDICATIVO & SUBJUNTIVO \\
\hline Cartas de tu e você (sujeito $2 \mathrm{P}$ ) & $136 / 295(46 \%)$ & $159 / 295(54 \%)$ \\
\hline Cartas de você (sujeito 2P) & $13 / 122(11 \%)$ & $109 / 122(89 \%)$ \\
\hline Cartas de $t u$ (sujeito $2 \mathrm{P}$ ) & $\mathbf{9 4 / 1 2 8}(\mathbf{7 3} \%)$ & $34 / 128(27 \%)$ \\
\hline TOTAL & $242 / 545(\mathbf{4 5} \%)$ & $302 / 545(\mathbf{5 5} \%)$ \\
\hline
\end{tabular}

Ao analisar o quadro geral apresentado no Quadro 1, verifica-se um acirrado nível de variação entre as construções imperativas estruturadas com formas verbais subjuntivas, em $55 \%$ dos dados (242 ocorrências), e indicativas, em $45 \%$ delas (302 ocorrências), dentre o total de 545 estruturas imperativas de 2P levantadas nas cartas cariocas dos séculos XIX e XX. A correlação entre as funções de sujeito de $2 \mathrm{P}$ (cartas de você-suj., cartas de $t u-s u j$., cartas de $t u \sim v o c \hat{e}$ e os dados de imperativo também de $2 \mathrm{P}$, ainda que, por um lado, confirmem a expectativa de que os cariocas cultos preferiram a estruturação do imperativo com formas de subjuntivo vinculadas ao você-suj., em $89 \%$ dos dados (109 ocorrências) nas cartas exclusivas de você-suj., por outro lado, já fornecem indícios do imperativo abrasileirado, nos termos de Scherre (2007), sobretudo nas cartas mistas (cartas de variação $t u \sim$ você como sujeitos de $2 \mathrm{P}$ ), em 46\% dos dados (136 ocorrências) e também, mesmo que minimamente, em 13 ocorrências (12\%), nas cartas de você-suj. Parece muito esclarecedor o fato de a maior expressão quantitativa do imperativo abrasileirado justamente se manifestar nas cartas em que tu e vocêse alternam na referência ao interlocutor, o que parece evidenciar o processo de reorganização do quadro pronominal do $\mathrm{PB}$ também repercutir nas construções imperativas de 2P. Como exemplificação, apresentam-se, de (01) a (03), ocorrências de construções imperativas estruturadas com formas verbais subjuntivas, bem como com formas indicativas, de (04) a (07), em cartas mistas e em cartas de você-suj., respectivamente. 
(01) [...] Como tens Você, a tua Mãe e Marido e Pae eirmãos passado? [...] Acceite o coração e a benção ... (JPF. RJ, 07.02.1877. (carta de tu/você-suj., imperativo associado a forma de subjuntivo))

(02) [...] Foi bom, Você voltar para Santa Fé, por que aqui teem adoecido muitas crianças [...] Você va pedindo a mamãe que lhe ensine a ler e escrever... (JPF. RJ, 15.04.1886. (carta de você-suj., imperativo associado a forma de subjuntivo))

(03) [...] Veja o que é a philosophia [...] Vôcê reze por meus estudos e vamos a outras noticias [...] (FPCAM. França, Vals, 27.12.1920. (carta de você-suj., imperativo associado a forma de subjuntivo))

(04) [...] Tudo n'ella me consolou tanto! até a linda lettra com que a escreveste. [...] agradeço de um modo especial a graça que quando pequenino de 2 mezes você alcançou n'este dia [...] Faze uma Communhão em reconhecimento a este favor, sim? [...] (ZPAM. RJ, 27.11.1912. (carta de $t u$ / você-suj., imperativo associado a forma de indicativo))

(05) [...] Immagine que cheguei até aonde se pode chegar. Minha Irmã, Você é toda minha e eu sou toda sua [...] Escreve-me sim? [...] (MLPCAM. PE, Olinda. 11.07.1920. carta de você-suj., imperativo associado a forma de indicativo)

(06) [...] Recebe meu Irmão querido... Você me avisa por favor... De novo te abraço com todo nosso amor fraterno e me darás a benção [...] (MRPCAM. 13.02.1933. (carta de $t u / v o c \hat{e}-s u j$., imperativo associado a forma de indicativo))

(07) [...] Pede aDeos minha [...] Filha pela saude de teu Pae [...] sendo provavel que a esta hora já Você tenha recebido. [...] (JPF. RJ, 16.07.1879 (carta de vocêsuj., imperativo associado a forma de indicativo))

Uma vez expostos os resultados gerais relacionados ao imperativo de 2P, passa-se a acompanhar, através do Gráfico 1, a sua disposição (545 ocorrências) no decorrer dos períodos de 1870 a 1889 (fase I), de 1890 a 1909 (fase II), de 1910 a 1929 (fase III) e de 1930 a 1949 (fase IV). A 
distribuição dos dados por intervalos temporais de dezenove anos foi motivada pela dinâmica variável do imperativo de $2 \mathrm{P}$ associado a formas de subjuntivo (imperativo supletivo) ou de indicativo (imperativo verdadeiro) nas missivas cariocas oitocentistas e novecentistas analisadas.

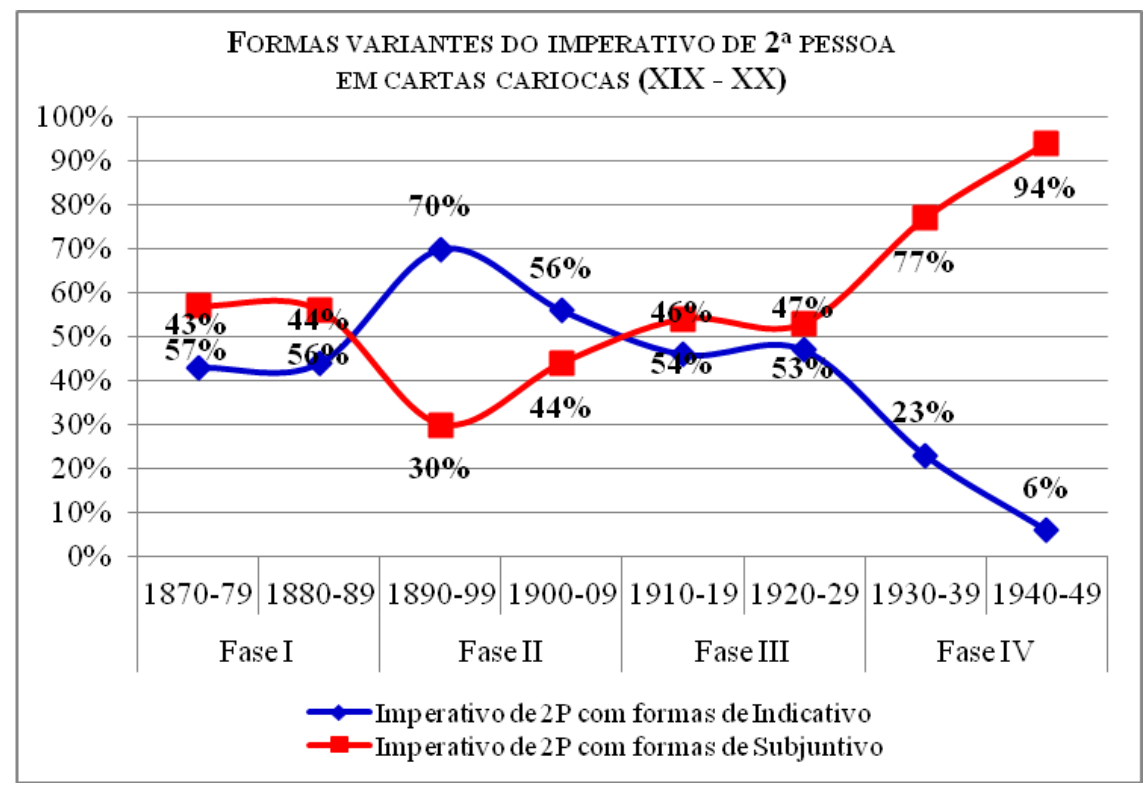

Gráfico 1 - As frequências de uso de formas verbais de indicativo e de subjuntivo na construção do imperativo de $2 \mathrm{P}$ distribuídas no decorrer de fins do século XIX (1872) até a $1^{a}$ metade do século XX (1948)

A análise do Gráfico 1 permitiu constatar as sinuosas curvas atingidas pelas formas indicativas e subjuntivas, legitimando-as, já em sincronias passadas, como produtivas estratégias variáveis de composição das estruturas imperativas de 2P. Na fase I, entre 1870 e 1899, observa-se a prevalência das formas subjuntivas (56\% entre 1870-1879, e 57\% entre 1880-1889), ainda que tenham se mostrado em alternância com as formas de indicativo (43\% entre 1870-1879 e 44\% entre 1880-1889). Entre 1890-1899 e 1900-1909, verifica-se uma inversão de comportamento em relação à expressão do 
imperativo de $2 \mathrm{P}$ que, em $70 \%$ e $56 \%$ dos dados, respectivamente, se deu preferencialmente, nessa fase II, com formas de indicativo. Na sequência, entre os anos de 1910 e 1929, fase III, voltam a predominar as formas subjuntivas (54\% e 53\%), ainda que acirradamente tenham voltado a dividir o mesmo espaço funcional com formas de indicativo (46\% e 47\%) nas estruturas imperativas de 2P. Dando continuidade ao movimento de ascendência das formas subjuntivas na construção do imperativo de 2P, percebe-se, entre os anos de 1930 e 1940, fase IV, a acentuada preferência dos missivistas cariocas pelo subjuntivo, com índices percentuais de $77 \%$ e $94 \%$, em detrimento das formas verbais indicativas que, com índices de $23 \%$ e $6 \%$, seguem, por sua vez, um movimento de vertiginoso declínio. Resguardadas as devidas ressalvas relativas ao fato de as epístolas cariocas reproduzirem o comportamento linguístico específico de informantes brasileiros unidos pelo mesmo laço familiar e que, atrelados também pelos mesmos interesses (religiosos), se corresponderam intensamente entre os séculos XIX e XX, há de se considerar que os dados de formas verbais indicativas, ao entrarem na estrutura do imperativo de $2 \mathrm{P}$ em contextos de você já, de certa forma, parecem prenunciar essa preferência brasileira discutida por Scherre com bases em dados sincrônicos do PB ("Vem pra Caixa você também”).

Considerando o foco específico deste trabalho, a identificação de vestígios do imperativo abrasileirado em sincronias passadas do $\mathrm{PB}$, apresentam-se os índices probabilísticos relacionados ao contexto de sujeito de 2P das cartas cariocas (cartas de tu-suj., cartas de você-suj., cartas de $t u$ /você-suj.) correlacionados aos dados de imperativo com formas verbais de indicativo no intuito de evidenciar qual(is) pronome(s) de $2 \mathrm{P}$ se mostraria(m) relevante(s) à aplicação da regra variável em questão (indicativo versus subjuntivo na composição do imperativo). O alto nível de significância atribuído pelo programa computacional Goldvarb a esse grupo de fatores (primeiro fator selecionado como grupo significante (.000) no processo de stepping up) evidencia a expressividade da correlação entre as estratégias verbais de composição do imperativo e as estratégias de referência ao sujeito de $2 \mathrm{P}$ do discurso. Assumindo o indicativo como variável dependente cujo valor de aplicação foi o de 0.457 na construção das formas verbais imperativas, expõem-se, no Quadro 2, os resultados vinculados à produtividade dessa regra variável. 
Quadro 2 - O imperativo construído com formas de indicativo em cartas de $t u$, em cartas de você-suj. e em cartas de $t u-s u j$.

\begin{tabular}{|c|c|c|}
\hline \multirow{3}{*}{$\begin{array}{c}\text { SUJEITOS PRONOMINAIS } \\
\text { DE 2 2a PESSOA } \\
\text { (NÍVEL DE SIGNIFICÂNCIA: .000) }\end{array}$} & \multicolumn{2}{|c|}{ IMPERATIVO DE 2a PESSOA (XIX-XX) } \\
\hline & \multicolumn{2}{|c|}{ INDICATIVO } \\
\hline & OCORRÊNCIAS (\%) & Pesos Relativos \\
\hline Cartas de tu e você (sujeito 2P) & $129 / 232(\mathbf{5 5} \%)$ & 0.534 \\
\hline Cartas de você (sujeito 2P) & $13 / 232(05 \%)$ & 0.142 \\
\hline Cartas de $t u$ (sujeito $2 \mathrm{P}$ ) & $90 / 232(39 \%)$ & 0.807 \\
\hline Total & $232 / 508(46 \%)$ & 0.457 \\
\hline
\end{tabular}

Com base na análise do Quadro 2, é possível verificar, através dos índices percentual e probabilístico - 55\% e 0.534 , respectivamente - que, em contextos de variação tu e você na função de sujeito de $2 \mathrm{P}$, as cartas movidas pela alternância $t u \sim$ você (cartas mistas) na referência ao sujeito de $2 \mathrm{P}$ mostraram-se propulsoras da aplicação do imperativo associado ao indicativo nas missivas analisadas, como ilustrado de (08) a (14).

(08) [...] Para responder as cartas que Você tem me escripto [...] Hoje eu não tenho mais tempo de escrever á Mamãe, por isso você agradece por mim [...] Que alegria quando eu voltar Padre para o Brasil, não é? Mamãe, Papae Papae Pedreira, todos ficarão contentissimos, não achas? [...] (JPCAM. Paris, 15.10.1905. carta mista)

(09) [...] e Você como Padre e como religioso bem póde comprender ás miserias do coração humano. Toma pois querido irmão um crucifixo, e lerás o coração de tua irmã!! [...] (MRPCAM. La Plata, 04.11.1911. carta mista)

(10) [...] Imagino como estás zangadinho com tua Jane... que, nem signal deu do recebimento de tua carta depois da viagem á Argentina [...] Você arranje seu negocio com Tio Janio. [...] agora reza muito e muito! [...] (MJPFM. 12.04.1925. carta mista) 
(11) [...] Lembra-te da palavra de D. Miguel: o mal de sua irmã é ter cabeça de mais. Você por ser aviadora, quer que todos vôem. Nem todas as Dorós tem azas como as tuas: cede, e cede tudo que possas, como te diria a nossa santa Mamãe. [...] (JPCAM. MG, Mariana, 16.11.1931. carta mista)

(12) [...] penso que estarás desejoso de saber como chegamos [...] depois que acabe Você me avisa por favor [...] Quando já saiba alguma noticia que me interessa sobre Você me avisa, pois sabe o gozo que terei. [...] (MRPCAM. Buenos Aires, 13.02.1933. carta mista)

(13) [...] Que te diria no dia $19^{\circ}$ dia de teus anos? tantas cousas ... e te abraçaria sem nunca acabar ... porem como nos separa tanta agua, recebe em espirito meu irmão amado os carinhos [...] graças á Deus que Você está escrevendo. Não te imaginas os preparativos que se faz em Buenos Aires para o Congresso Eucharistico estão todos contentes com o Cardeal que vão ter. [...] (MRPCAM. La Plata, 28.11.1933. carta mista)

(14) [...] acabaram as hostias que Você consagrou, não pude deixar de chorar - por ahi Você vê minha amizade por meu irmão. Recebe lembranças de Don Oreste Dona Agusta e do pobre quintero Don Juan. Quando visite o tumulo de nossa santa mãe não te esqueças de pedir pelas minhas intenções. [...] (MRPCAM. La Plata, 01.02.1948. carta mista)

As altas produtividade e probabilidade de estruturação do imperativo com formas de indicativo (55\% e 0.534) justamente em cartas em que o você alterna com o tu expõem, já em sincronias passadas do PB, pistas da atual realidade linguística do $\mathrm{PB}$. Em relação ao imperativo abrasileirado (deixa, recebe, abre, dá, diæz vai nos contextos de você das revistas em quadrinhos da Turma da Mônica), Scherre (2007, p. 210-211), ao percorrer, em uma análise em tempo real de longa duração, desde a década de 70 do século XX até o ano 2005, evidencia uma tendência ao uso do imperativo com formas de indicativo em ambiência de você-suj. a partir do ano de 1983 (entre 1970 e 1971 com 0.04; em 1983 com 0.08; entre 1985 a 1998 com 0.37; entre 1998 e 1999 com 0.44, nos anos 2001, 2002, 2004 e 2005 com 0.62). Ao recuar até fins do século XIX e $1^{a}$ metade do século XX, verifica-se uma 
tendência ao imperativo abrasileiro entre os anos 2001 e 2005, como visto por Scherre (2007).

Uma vez apresentados os resultados gerais, bem como os resultados específicos voltados para as formas imperativas associadas ao indicativo, sobretudo em contextos de variação $t u / v o c \hat{e}$, passa-se à discussão da contribuição das categorias sociais gênero e faixa etária em relação às estratégias variáveis de composição do imperativo de $2 \mathrm{P}$ no $\mathrm{PB}$.

\subsection{As construçôes imperativas de $2^{a}$ pessoa: o gênero e a faixa etária do missivista em foco}

De um modo geral, observam-se, com base no Gráfico 2, as estruturas de imperativo verdadeiro em acirrada convivência com as estruturas de imperativo supletivo entre os missivistas cariocas analisados.

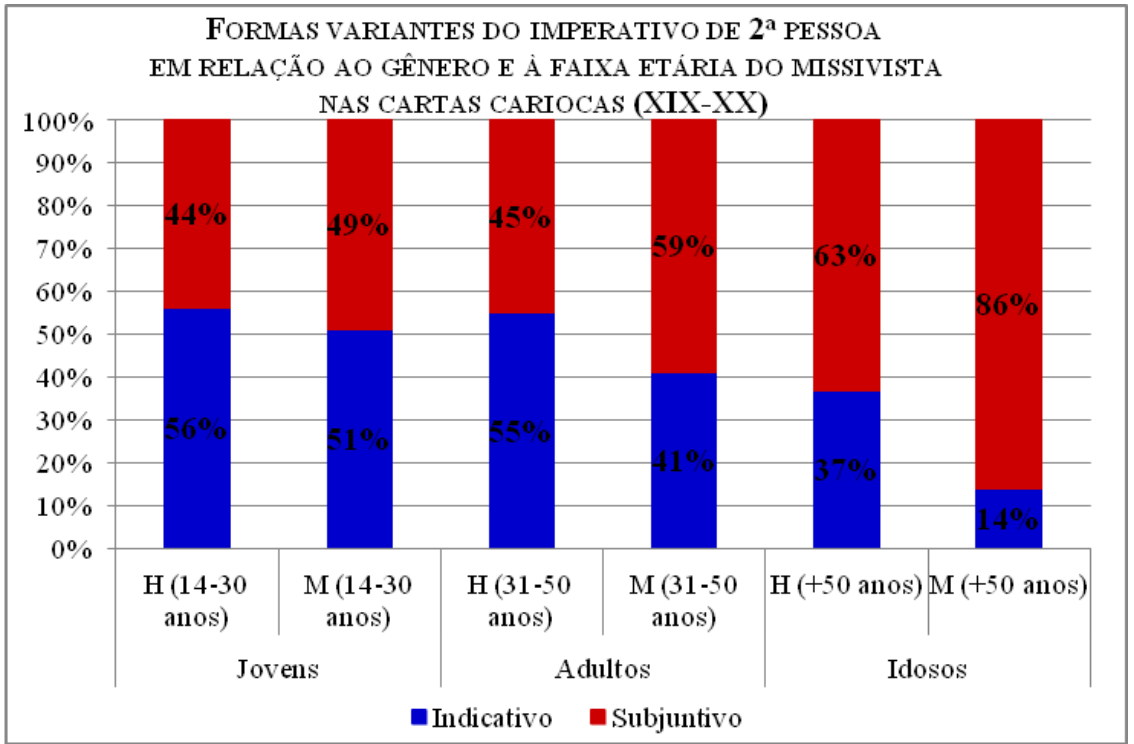

Gráfico 2 - As frequências de uso de formas verbais de indicativo e de subjuntivo na construção do imperativo de $2 \mathrm{P}$ distribuídas pelo gênero e faixa etária dos missivistas (XIX - XX) 
Correlacionam-se os gêneros dos informantes às suas respectivas faixas etárias no intuito de entrever a interferência de tais categorias sociais na expressão variável do fenômeno linguístico em análise: construções de imperativo verdadeiro ou construções de imperativo supletivo na referência à $2 \mathrm{P}$ ? Entre os jovens missivistas cariocas, nota-se que os homens e as mulheres equilibram-se entre as formas indicativas (56\%, 28 ocorrências, e 51\%, 41 ocorrências) e subjuntivas (44\%, 22 ocorrências, e 49\%, 39 ocorrências), respectivamente, ainda que tenham preferido o imperativo verdadeiro nessa etapa da vida. $\mathrm{O}$ fato de os missivistas mais jovens privilegiarem as construções imperativas sedimentadas com o modo indicativo parece prenunciar um quadro de variação e mudança em progresso discutida por Scherre (2007). Em (15) e (16), expõem-se dados que contemplam a alternância entre o imperativo supletivo e o imperativo verdadeiro. Em (15), verifica-se um dado do imperativo associado ao subjuntivo em contexto de carta de vocî-suj. produzido por uma mulher jovem. Por outro lado, observe-se, em (16), que o missivista jovem, em uma carta de tu-suj., coordena duas orações imperativas: na primeira oração, o imperativo mostra-se estruturado com forma verbal indicativa (“... Faze um momento por mim...”) e, na mesma sequência discursiva, tem-se, na segunda oração, o imperativo construído a partir de uma forma verbal subjuntiva (“... e dê-me tua bençam...”), expondo a dinâmica variável do imperativo gramatical no PB dos séculos XIX e XX.

(15) [...] se você o visse agora não o conheceria talvez [...] Elle coitado [...] está muito saudoso porem resignado mandando licença para ir até ao mandando licença para ir até ao Pará, imagine! [...] (MAPCAM. Friburgo, RJ, 01.08.1909. Mulher jovem - 22 anos)

(16) [...] Adeus, meu irmãosinho. Peço a São Estanislau por ti por teus trabalhos apostolicos. Faze um momento por mim e por meus estudos, e dê-me tua bençam sacerdotal. [...] (FPCAM. França, Vals, 13.11.1921. Homem jovem 28 anos)

Entre os adultos e os idosos atenuou-se, ainda que minimamente, o acirramento da competição entre o imperativo verdadeiro e o imperativo supletivo, como é possível observar de (17) a (25). Em relação aos adultos 
cariocas, observam-se novamente os homens cariocas como os que mais acionaram o indicativo, em $55 \%$ dos dados (52 ocorrências) em concorrência com o subjuntivo, em $45 \%$ dos dados (42 ocorrências) na formação do imperativo de $2 \mathrm{P}$. As mulheres, por outro lado, mantiveram a opção pelo subjuntivo, em 59\% dos dados (139 ocorrências) ainda que, em 41\% dos dados (96 ocorrências), em açulada concorrência, pois, com as formas indicativas na expressão gramatical do imperativo de 2P. Em (19) e (20), ilustra-se, com dados de imperativo originado a partir de formas verbais indicativas, a expressão do imperativo abrasileirado em cartas femininas de você-suj. Em (21), observa-se, em uma carta movida pela alternância tu/você na função de sujeito de $2 \mathrm{P}$, a dinâmica de variação entre o indicativo (pede) e o subjuntivo ( $p e c ̧ a)$ na formação do imperativo. Acrescente-se a isso o fato de o missivista ter rasurado a forma verbal ' has', em 'hás de apreciar', ao referir-se ao seu interlocutor, em uma clara evidência da variação entre as formas tu e você expressas também pelas formas peça e pede em um mesmo período composto e sintaticamente misto, estruturado por coordenação e por subordinação. Acima dos 50 anos, também os homens cariocas, em $63 \%$ dos dados (34 ocorrências), mostraram-se mais propensos do que as mulheres, em $59 \%$ dos dados (86\%, 24 ocorrências), ao uso do imperativo associado a formas de subjuntivo. Observe-se assim que, em 37\% (20 ocorrências) e 14\% (4 ocorrências) dos dados, respectivamente, os homens e as mulheres idosos já expuseram, ainda que em menor escala, evidências do imperativo estruturado em formas verbais indicativas, como ilustrado de (22) a (25).

(17) [...] Pela tua letra já se conhece que tens feito alguns progressos na calligraphia [...] Diz̧e as tuas manas que com vagar escrever lhes hei, não me restando hoje mais tempo [...] (JPCF. Quinta da União, 25.12.1872. Homem adulto - 46 anos)

(18) [...] Sê por conseguinte muito obediente a teus superiores, porque assim o manda Nosso Senhor. [...] Se encontrares outros mais intelligentes não te incommodes com isso, mas estude mais e mais, que chegarás Tambem e ás veses com mais segurança. [...] (RJ, 18.12.1896. Homem adulto - 45 anos) 
(19) [...] e Você como Padre e como religioso bem póde comprender ás miserias do coração humano. Toma pois querido irmão um crucifixo, e lerás o coração de tua irmã!! (MRPCAM. La Plata, 04.11.1911. Mulher adulta 33 anos)

(20) [...] Para a biographia de Mamãe ve se serve estes. [...] Gostei muito dos pensamentos de Papae e Mamãe na estampa, como você teve boa ideia! [...] (MBPCAM. SP, 22.10.1925. Mulher adulta - 42 anos)

(21) [...] você pode pedir licença de empregar sua legitima como quiseres, porque não a empregarás n'este testemunho de amor à Mamãe [...] você, meu irmão, has ${ }^{5}$ de apreciar. [...] Peça portanto a licença de 2 ou 3 contos, si não quizeres dal-os, pede licença de emprestal-os. [...] (JPCAM. Bahia, 08.07.1920. Homem adulto - 39 anos)

(22) [...] Escreve me dizendo quando vem [...] Dá um abraço ao Jeronimo, á Zelia [...] até que consigas della um sorriso que já é expressivo [...] (JPCF. Linda Vista, 01.01.1886. Homem idoso - 60 anos)

(23) [...] E tu minha Jane Como estás dos ouvidos? [...] Pede fervorosamente a São José [...] (JCAM. RJ, 26.01.1908. Homem idoso - 57 anos)

(24) [...] Reze bastante, a Deos nada é impossivel [...] Que contente fiquei de Você estar em Friburgo e Jane ahi no Rio: escrevi- a Amalia a pouco tempo. [...] Sempre que poder me escreva. [...] Recebe o coração affectuoso e um terno osculo [...] (MLPCAM. PE, Tamarineira, 28.01.1933. Mulher idosa - 53 anos)

(25) [...] Quando acabaram as hostias que Você consagrou, não pude deixar de chorar - por ahi Você vê minha amizade por meu irmão. Recebe lembranças

\footnotetext{
${ }^{5} \mathrm{Na}$ forma verbal "hás", observa-se que o morfe [-s], marca formal da noção de $2^{\mathrm{a}}$ pessoa de singular (P2), foi riscada. Possivelmente, reflete uma correção do autor para manter a relação de harmonia morfossintática entre o sujeito de segunda pessoa do discurso (a forma "você") e o verbo em sua forma de terceira pessoa, em conformidade com os preceitos da gramática tradicional.
} 
de Don Oreste Dona Agusta e do pobre quintero Don Juan. [...]. (MRPFM. La Plata, 01.02.1948. Mulher idosa - 70 anos)

Isso posto, passa-se a correlacionar os dados das estratégias de construção do imperativo de $2 \mathrm{P}$ com os resultados alcançados por Rumeu (2013, p. 155) para a alternância tu e você-suj., através do Gráfico 3 (138 dados), levantados em 30 cartas das quais foram excluídas todas as ocorrências de imperativo de 2P. Acredita-se, pois, que a confluência entre as formas de estruturação do imperativo (indicativo ou subjuntivo), bem como a competição $t u / v o c \hat{e}$-sujeito dialogam entre si, parecendo influenciadas pelas categorias sociais gênero e faixa etária dos missivistas cariocas analisados.

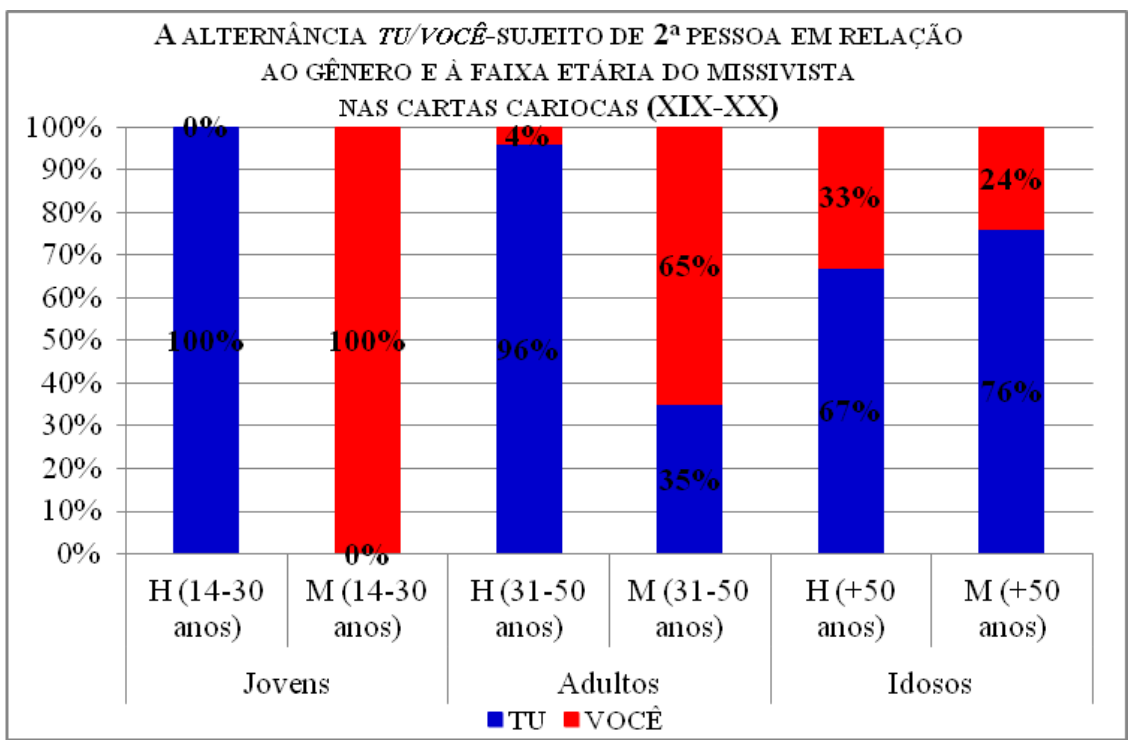

Gráfico 3 - A alternância $t u / v o c \hat{e}-s u j$. entre os homens e mulheres jovens, adultos e idosos da família Pedreira Ferraz-Magalhães entre os séculos XIX e XX, conforme Rumeu (2013)

Com base na análise do Gráfico 3, é possível constatar uma distribuição variável entre as formas tu e você para a referência ao sujeito de $2 \mathrm{P}$ do discurso. 
Os jovens cariocas revelaram comportamentos opostos. Enquanto os homens privilegiaram categoricamente o $t u$ (8 ocorrências), as mulheres optaram pelo você (10 ocorrências). Entre os adultos cariocas, verifica-se a prevalência do tu entre os homens, em 96\% dos dados (22 ocorrências) em oposição a somente uma ocorrência do você, ao passo que as mulheres elegeram o você em 65\% dos dados (15 ocorrências), ainda que o $t u$, em 35\% dos dados (8 ocorrências), se apresentasse como uma considerável opção de referência à $2 \mathrm{P}$. Em relação aos idosos cariocas, verifica-se acentuada tendência para $t u$. Os homens idosos em análise se mostraram mais propensos ao tu em 67\% dos dados (10 ocorrências) do que ao você, que somente atuou em 5 ocorrências (33\%). As mulheres idosas, ainda que também se mostrassem mais inclinadas ao $t u$, em $76 \%$ dos dados (45 ocorrências), usaram o inovador você em $24 \%$ dos dados (14 ocorrências). Em uma espécie de balanço analítico acerca do comportamento de homens e mulheres cariocas, entre os séculos XIX e XX, constata-se uma divergência de comportamentos marcada pela presença do inovador você na produção escrita das mulheres jovens, mesmo que com baixos índices de produtividade, o que, de certa forma, já parece evidenciá-las mais propensas ao encaminhamento histórico da mudança em direção à inserção do você-suj. de $2 \mathrm{P}$ no quadro pronominal do PB. Ao correlacionar tais resultados de sujeito aos explicitados no Gráfico 2, para a expressão variável do imperativo de $2 \mathrm{P}$ também entre os Pedreira FerrazMagalhães, observa-se a mulher como a figura que não só desponta mais inclinada ao uso do você na referência à $2 \mathrm{P}$, mas também por selecionar, sobretudo na juventude $(51 \%)$, as formas indicativas na construção do imperativo (imperativo abrasileirado). Essas duas opções (pelo você-suj. e pelo imperativo associado ao indicativo em contexto de variação tu e você-suj. e também em contexto de você-suj.) aproximam também os dois fenômenos linguísticos analisados em relação ao fato de nenhum deles sofrer algum tipo de rechaço social. Nesse sentido, a divergência de comportamentos entre homens e mulheres da família Pedreira Ferraz-Magalhães conduz a outra questão: como entender a(s) motivação(ões) social(is) para a produtividade do imperativo abrasileirado, nos termos de Scherre (2007), no discurso feminino escrito informal das mulheres de ilustres famílias brasileiras?

Assumindo um encaminhamento diverso do assumido pelo você, a partir do século XIX, em Portugal, observa-se que a aristocracia brasileira emprega tal forma inovadora nos Oitocentos, como evidencia Soto (2007), 
com base na análise de missivas brasileiras oitocentistas e novecentistas. $\mathrm{O}$ fato de o você ainda resguardar, por um lado, o prestígio da Forma Nominal de Tratamento para a realeza que a originou (vossa mercê) expõe o conservadorismo do PB. Por outro lado, segundo Soto (2007), o emprego de você em cartas-diário, pela Condessa de Barral, ao se referir ao imperador D. Pedro $\mathrm{II}^{6}$; em cartas familiares redigidas pela missivista mineira Maria Guilhermina Penna ${ }^{7}$, ao eleger o você para tratar o filho Affonso Penna Júnior, sobretudo ao atingir a velhice (PEREIRA, 2012); em cartas pessoais trocadas em 1904 e $1906^{8}$ entre os amigos baianos Rui Barbosa e José Marcelino (senador e governador da Bahia (MENON, 2006)); em cartas familiares confeccionadas pela vovó Bárbara Ottoni ${ }^{9}$ - redatora mediana nos termos

${ }^{6}$ Excertos de Cartas da Condessa de Barral e do Imperador D. Pedro II, em 1869: Condessa de Barral: "Eu fiquei tão contente que nem sei como pude descer a escada do colégio. Meu pensamento foi de Montmartre ao Brasil e $V$. havia de sentir o fluido pelo seu coração." Imperador D. Pedro II: "Ah! se senti! Você sabe que bem lhe quero! "Condessa de Barral: "Ah! Se sei!" (cf. SOTO, 2007, p.159).

7 "Vocétem recebido 20 volumes que o Mordomo mandou? Escrevi uma carta de 4 paginas e vocé diz que não recebeu, não gostei nada d'isso. [...] Pela semana Santa vocé poderia vir nos visitar [...]" (Carta de Maria Guilhermina Penna a Affonso Penna Júnior em 01/03/1909 apud PEREIRA, 2012, p. 108).

${ }^{8}$ José Marcelino a Rui Barbosa: "Caro colega e amigo Rui Barbosa. [...] Conhece V.a rica e vasta região dos Lençóis e os interêsses de ordem pública, a que a administração tem de atender, ali, onde são frequentes as perturbações. [...] Conhece $V$. melhor que eu a questão da propriedade dos terrenos de marinha e das minas [...] e perante o Congresso e o Govêrno Federal a Bahia entrega-se a $V$. e a todos os seus representantes, dos quais deve $V$. ser o centro de ação por todos os titulos". (José Marcelino, 27.06.1904 apud MENON, 2006, p. 153).

Rui Barbosa a José Marcelino: "Felizmente recebi do Severino, ontem, um telegrama, onde me diz: 'Louvo-me no seu pensar e sentir; sou solidário seu modo de agir'; e $V$. mesmo termina o seu com estas palavras: 'Resolva o que seu espírito esclarecido, criterioso e experimentado lhe ditar [...]" (Rui Barbosa, 12.10.1906 apud MENON, 2006, p. 153).

9 "A 12 escrevi a Christiano e hoje a voce. Estimei muito as boas noticias que tive que voce está muito estudiozo e que está muito adiantado. Continue para nos dar muito gosto e a sua Mae aquem abraçarás por mim. [...] Teabraça e a Christiano Sua Avo e Amiga. Barbara. (Carta de Barbara Ottoni ao neto Mizael, em fins do século XIX apud LOPES; MACHADO, 2005, p. 53. Carta 41, avó). 
de Barbosa (2005) - ao também preferir, no Brasil de fins do século XIX, o você para fazer referência aos seus netos, já se sobressaem como legítimos indícios do acelerado processo de dessemantização alcançado pelo você a adquirir, no Brasil, o inovador domínio da solidariedade.

Segundo a apreciação de Labov (1994), em processos de mudança linguística de baixo para cima (change from bellow), as mulheres tendem a empregar mais as formas inovadoras que os homens, bem como também evidenciado por Lopes (1993, 2003) e Zilles (2005) em relação à implementação do a gente no sistema pronominal do PB, reiterando, pois, as considerações de Lopes e Machado (2005), Chaves (2006), Marcotulio, Silva e Lopes (2007), Soto (2007), Rumeu (2008) e Pereira (2012) acerca do papel da mulher no que se refere à inserção do você no PB. Assume-se que o empreendedorismo linguístico das mulheres está no fato de escolherem uma forma que se inseriu a posteriori no quadro pronominal do $\mathrm{PB}$ como resultado de um processo gradual e paulatino de uma mudança linguística de cima para baixo (change from above (LABOV, 1994)). Nesse sentido, em consonância com Scherre e Yacovenco (2011, p. 139), que admitem "as mulheres estarem à frente" em processos de mudança com consciência social (change from above), relacionados a fenômenos linguísticos menos marcados socialmente, como é o caso não só do contexto de inserção do você no sistema pronominal do $\mathrm{PB}$, mas também do fenômeno do imperativo abrasileirado, estruturado a partir de uma forma verbal indicativa em conexão justamente com o inovador você, o que certamente passa pela compreensão acerca do gênero sociocultural consubstanciado na figura da mulher brasileira.

Ao redirecionar o foco desta análise ao encaixamento dessa mudança linguística na matriz social (embedding problem), é possível entender que a preferência das mulheres pelo você, menos direto e invasivo que o tu pronominal, se harmoniza "com uma conduta específica", resguardada pelo recato da subordinação a uma estrutura familiar patriarcal mais acentuada até o século XIX, conforme Samara (2004). Ainda que consciente da implicação social do tratamento do seu interlocutor por você e, ao que tudo indica, também inconsciente em relação à sua opção pelo imperativo coindexado a formas verbais de indicativo, a mulher-missivista brasileira, nas eras oitocentista e novecentista do $\mathrm{PB}$, prefere não só um pronome (você) que está se inserindo no quadro pronominal, dotado ainda de uma relativa 
formalidade, mas também uma estrutura imperativa legitimamente brasileira também desprovida de rechaço social (“... Você me avisa por favor...", MRPFM, 13.02.1933), o que permite confirmar a hipótese laboviana de que a mulher, sobretudo a mulher jovem, como observado neste trabalho, tende a se deixar conduzir na direção histórica da mudança linguística.

\section{Considerações Finais}

As cartas familiares da família Pedreira Ferraz-Magalhães atestaram a relevância de uma amostra de cartas bem controlada em relação ao delineamento dos perfis sociais dos missivistas, que, certificadamente cariocas, se mantinham em constantes peregrinações dentro e fora do Brasil como representantes da fé católica, o que os evidenciava como profícuos missivistas entre os seus familiares. Passa-se a algumas generalizações, tendo em vista as questões norteadoras deste trabalho.

Entre os Pedreira Ferraz-Magalhães, a composição estrutural do imperativo de $2 \mathrm{P}$ se deu preferencialmente com as formas verbais de subjuntivo, confirmando a hipótese inicial de que tal variante seria a privilegiada em contextos de você-suj., justificada pelo alto grau de escolaridade dos missivistas e pela intimidade que mantinham com a norma-padrão que, por sua vez, prevê a harmonização entre formas que ativam a $3^{\text {a }}$ pessoa formal (você) e o subjuntivo na estruturação do imperativo de $2 \mathrm{P}$. Em relação ao imperativo abrasileirado, levantaram-se vestígios dessa especificidade do PB, tão produtiva na atual fala carioca, já na escrita carioca de sincronias passadas do PB (séculos XIX-XX), cumprindo-se, pois, o objetivo principal desta análise.

A produtividade do imperativo associado a formas de indicativo entre os jovens cariocas (homens e mulheres) sugeriram um quadro de aparente mudança em progresso que parece ser estimulado, sobretudo, pela preferência do você-suj. acionada pelas mulheres (cf. Gráfico 3), visto que as pressões sociais da fase adulta, segundo Sankoff (2006), parecem subsidiar as opções mais conservadoras, comportamento observado entre os idosos cariocas, não só no que se refere ao sujeito de $2 \mathrm{P}$ (tu), mas também em relação à composição estrutural imperativa associada a formas verbais de subjuntivo. Em suma, nas missivas analisadas, enquanto os jovens pareceram 
encaminhar-se na direção histórica da mudança em progresso (instauração do imperativo abrasileirado pelo espaço geográfico carioca), os adultos e os idosos pareceram se deixar conduzir pelos princípios da norma-padrão, expressando um movimento de retração da produtividade do imperativo abrasileirado.

\section{Referências}

AGUILLAR R. C. Presencia de lo oral en lo escrito: la transcripción de las declaraciones en documentos indianos del siglo XVI. In:

OESTERREICHER, W.; STOLL, E.; WESCH, A. (Ed.). Competencia escrita, tradiciones discursi-vas y variedades lingüisticas: aspectos del español europeo y americano en los siglos XVI y XVII. Tubingen: Narr, 1998. p. 219-242.

BARBOSA, A. G. Tratamento dos corpora de sincronias passadas da língua portuguesa no Brasil: recortes grafológicos e lingüísticos. In: LOPES, C. R. S. A norma brasileira em construção: fatos lingüísticos do século 19. Rio de Janeiro: UFRJ; FAPERJ, 2005. p. 25-43.

BONFÁ, C. R. Z.; PINTO, I. A.; LUIZ, I. Imperativo: uma comparação entre Lages e Florianópolis. Florianópolis: UFSC, 1997. (Série de Estudos Diacrônicos).

CARDOSO, D. B. B. O imperativo gramatical no português do Brasil. Revista de Estudos da Linguagem, Belo Horizonte, v. 14, n. 2, p. 317-240, jul./dez. 2006.

CHAVES, E. Implementação do pronome você: a contribuição de pistas gráficas. 2006. Dissertação (Mestrado em Linguística) - Universidade Federal de Minas Gerais, Belo Horizonte.

CONDE SILVESTRE, J. C. Sociolingüística histórica. Madrid: Gredos, 2007.

CUNHA, C. A questão da norma culta. Rio de Janeiro: Tempo Brasileiro, 1985. 
CUNHA, C.; CINTRA, L. F. L. Nova gramática do português contemporâneo. Rio de Janeiro: Nova Fronteira, 1985.

FARACO, C. A. The imperative sentence in Portuguese: a semantic and historical discussion. 1982. Thesis (PhD in Modern Languages) - University of Salford, Salford.

GUY, G.; ZILLES, A. Sociolingüistica quantitativa: instrumental de análise. São Paulo: Parábola, 2007.

HERNÁNDEX-CAMPOY, J. M.; CONDE SILVESTRE, J. C. The handbook of historical Sociolinguistics. New York: Wiley Blackwell, 2014 [2006].

LABOV, W. Principles of Linguistic change: internal factors. Cambridge: Blackwell Publishers, 1994. v. I.

LABOV, W. Principles of Linguistic change: social factors. Cambridge: Blackwell Publishers, 2001. v. 2.

LOBO, T. C. F. Para uma sociolingüística histórica do português no Brasil. Edição filológica e análise lingüística de cartas particulares do Recôncavo da Bahia, século XIX. 2001. Tese (Doutorado em Filologia e Língua Portuguesa) Universidade de São Paulo, São Paulo. v. 2.

LOPES, C. R. S. Nós e a gente no português falado culto do Brasil. 1993.

Dissertação (Mestrado em Língua Portuguesa) - Universidade Federal do Rio de Janeiro, Rio de Janeiro.

LOPES, C. R. S. A inserção de 'a gente' no quadro pronominal do português. Frankfurt: Vervuert; Madri: Iberoamericana, 2003. v. 18.

LOPES, C. R. S.; CAVALCANTE, S. A cronologia do voceamento no português brasileiro: expansão de você-sujeito e retenção do clítico-te. Lingüistica, Madri, v. 25, p. 30-65, 2011.

LOPES, C. R. S.; RUMEU, M. C. de B. O quadro de pronomes pessoais do português: as mudanças na especificação dos traços intrínsecos. In: CASTILHO, A. T. et al. (Org.). Descrição, história e aquisição do português brasileiro. Estudos dedicados a Mary Kato. São Paulo: Fapesp; Campinas: Pontes, 2007. p. 419-435. 
LOPES, C. R. S.; MACHADO, A. C. M. Tradição e inovação: indícios do sincretismo entre a segunda e a terceira pessoas nas cartas dos avós. In: LOPES, C. R. S. (Org.). A norma brasileira em construção: fatos lingüísticos do século 19. Rio de Janeiro: UFRJ; FAPERJ, 2005. p. 45-66.

LOREGIAN-PENKAL, L. (Re)análise da referência de segunda pessoa na fala da região Sul. 2004. Tese (Doutorado em Letras) - Universidade Federal do Paraná, Curitiba.

LUCCHESI, D. A constituição histórica do português brasileiro como um processo bipolarizador: tendências atuais de mudança nas normas culta e popular. GROBE, S.; ZIMMERMANN, K. (Ed.). "Substandard" $e$ mudança no português do Brasil. Frankfurt am Main: TFM, 1998. p. 73-99.

MARCOTULIO, L. L.; SILVA, P. F.; LOPES, C. R. S. A norma brasileira em construção: a variação entre tu e você no início do século $\mathrm{XX}$. In:

CONGRESSO INTERNACIONAL DA ASSOCIAÇÃO INTERNACIONAL DE LINGUÍSTICA DO POR-TUGUÊS - AILP, 2., 2007, Rio de Janeiro. (Comunicação oral).

MATEUS, M. H. M.; BRITO, A. M.; FARIA, I. H . Gramática da língua portuguesa. 2. ed. Lisboa: Caminho, 2003.

MENON, O. P. S. O imperativo no português do Brasil. 1984. Dissertação (Mestrado em Letras) - Universidade Católica do Paraná, Curitiba.

MENON, O. P. S. A história de você. In: GUEDES, M.; BERLINCK, R. A.; MURAKAWA, C. A. A. (Org.). Teoria e análise lingüísticas: novas trilhas. Araraquara: Laboratório Editorial FCL/UNESP; São Paulo: Cultura Acadêmica, 2006. p. 99-160.

MOLLICA, M. C; BRAGA, M. L. Introdução à Sociolingüistica: o tratamento da variação. São Paulo: Contexto, 2004.

PAIVA, M. C.; DUARTE, M. E. L. Mudança lingüística: observações no tempo real. In: MOLLICA, M. C.; BRAGA, M. L. (Orgs.) Introdução à Sociolingüistica: o tratamento da variação. São Paulo: Contexto, 2004. p. 179-190. 
PAGOTTO, E. G. Norma e condescendência, ciência e pureza. Lingua e instrumentos lingüisticos, n. 2, p. 49-68, 1998.

PEREIRA, R. O tratamento em cartas amorosas e familiares da Familia Penna: um estudo diacrônico. 2012. Dissertação (Mestrado em Língua Portuguesa) Universidade Federal do Rio de Janeiro, Rio de Janeiro.

RIVERO, M. Negation, imperatives and wackernagel effects. Rivista di Linguistica, v. 6, n. 1, p. 39-66, 1994.

RIVERO, M.; TERZI, A. Imperatives, V-movement and logical mood. Journal of Linguistics, v. 31, n. 2, p. 301-332, 1995.

ROCHA LIMA, C. H. Gramática normativa da língua portuguesa. Rio de Janeiro: José Olympio, 2002 [1972].

ROMAINE, S. Socio-historical Linguistics: its status and methodology. New York: Cambridge University Press, 2010 [1982].

RUMEU, M. C. de B. Para uma história do Português no Brasil: formas pronominais e nominais de tratamento em cartas setecentistas e oitocentistas. 2004. Dissertação (Mestrado em Língua Portuguesa) Universidade Federal do Rio de Janeiro, Rio de Janeiro. 2v.

RUMEU, M. C. de B. A implementação do 'você' no português brasileiro oitocentista e novecentista: um estudo de painel. 2008. Tese (Doutorado em Língua Portuguesa) - Universidade Federal do Rio de Janeiro, Rio de Janeiro. 2v.

RUMEU, M. C. de B. Lingua e sociedade: a história do pronome 'você' no português brasileiro. Rio de Janeiro: Ítaca; FAPERJ, 2013.

SAMARA, E. M. A família brasileira. São Paulo: Brasiliense, 2004.

SAMPAIO, D. A. Modo imperativo: sua manifestação/expressão no português contemporâneo. 2001. Dissertação (Mestrado em Letras) Universidade Federal da Bahia, Salvador.

SANKOFF, G. Age: Apparent time and real time. In: Encyclopedia of Language and Linguistics. $2^{\text {nd }}$ ed. Article Number: LALI: 01479. 2006. 
SAUSSURE, F. Curso de Lingüistica Geral. São Paulo: Cultrix, 2008 [1915].

SCHERRE, M. M. P. Norma e uso: o imperativo no português brasileiro. In: DIETRICH, W.; NOLL, V. (Org.). O Português do Brasil: perspectivas da pesquisa atual. Frankfurt am Main: Vervuert; Madrid: Iberoamericana, 2004. v. 1. p. 231-260.

SCHERRE, M. M. P. Aspectos sincrônicos e diacrônicos do imperativo gramatical no português brasileiro. Alfa, São Paulo, v. 51, n. 1, p. 189-222, 2007.

SCHERRE, M. M. P.; YACOVENCO, L. C. A variação linguística e o papel dos fatores sociais: o gênero do falante em foco. Revista da ABRALIN, Natal, n. esp., p. 121-146, 2011. Disponível em: <http:// bit.do/cUFMF>. Acesso em: 05 ago. 2012.

SCHERRE, M. M. P. et al. Variação dos pronomes "tu" e "você". In: MARTINS, M. A.; ABRAÇADO, J. (Org.). Mapeamento sociolinguístico do português brasileiro. São Paulo: Contexto, 2015. p. 133-172.

SEARLE, J. Speech acts. Cambridge: Cambridge University Press, 1969. SOTO, U. Cartas através do tempo: o lugar do outro na correspondência brasileira. Niterói: Editora da UFF, 2007.

ZILLES, A. The development of a new pronoun: The linguistic and social embedding of a gente in Brazilian Portuguese. Language Variation and Change, v. 17, p. 19-53, 2005.

WEINREICH, U.; LABOV, W.; HERZOG, M. I. Empirical foundations for a theory of language change. In: LEHMANN, W.; MALKIEL, Y. Directions for historical linguistics. University of Texas Press, 1968. p. 95-195. 